\title{
Penerapan Model Pembelajaran Project Based Learning Menggunakan Tour Builder Pada Peserta Didik Kelas X SMAN 1 Kaliorang (Materi : Dinamika Hidrosfer dan Dampaknya Terhadap Kehidupan)
}

\author{
Kusnayati $^{{ }^{*}}$, Laili Komariyah ${ }^{2}$, Yulian Widya Saputra ${ }^{3}$ \\ 1,3 Program Studi Pendidikan Geografi, Fakultas Keguruan dan IImu Pendidikan, \\ Universitas Mulawarman \\ 2 Program Studi Pendidikan Fisika, Fakultas Keguruan dan IImu Pendidikan, \\ Universitas Mulawarman
}

Korespondensi:* kusnayati.spd.soon@gmail.com

\begin{abstract}
Abstrak
Model pembelajaran project based learning ( $\mathrm{PjBL}$ ) dengan media pembelajaran tour builder dapat membantu merealisasikan objek geografi dalam kelas dan lebih mudah dipahami. Penelitian bertujuan untuk mengetahui respon peserta didik terhadap model pembelajaran PjBL menggunakan tour builder di kelas X IPS SMA Negeri 1 Kaliorang dan hasil belajar peserta didik. Penelitian ini menggunakan desain pre-experimental dengan rancangan time series, tes dilakukan setiap pertemuan. Instrumen untuk mengambil respon adalah angket dengan analisis statistik deskriptif persentase dan intrumen untuk hasil belajar adalah post tes dengan analisis yang digunakan adalah N-Gain. Hasil penelitian menunjukan bahwa respon peserta didik terhadap penerapan model pembelajaran PjBL menggunakan tour builder cukup baik dengan kriteria indeks respon sebesar $73 \%$ dan terdapat peningkatan hasil belajar peserta didik setiap pertemuan sebesar $0,45 \mathrm{~g}$ berdasarkan indeks gain. Hendaknya pendidik menjadikan model pembelajaran $\mathrm{PjBL}$ menggunakan tour builder sebagai alternatif untuk diterapkan di kelas pada materi tertentu, guna meningkatkan hasil belajar peserta didik.
\end{abstract}

Kata Kunci : project based learning, tour builder, respon peserta didik, hasil belajar

\section{Application of Project Based Learning Model Using Tour Builder for Class X Students SMAN 1 Kaliorang (Material: Hydrosphere Dynamics and Its Impact on Life)}

Abstract

The project based learning $(\mathrm{PjBL})$ learning model with tour builder learning media can help realize geographic objects in class and are easier to understand. The study aims to determine the response of students to the PjBL learning model using a tour builder in class $X$ IPS SMA Negeri 1 Kaliorang and the learning outcomes of students. This study used a pre-experimental design with a time series design, tests were carried out every meeting. The instrument for taking in the response was a questionnaire with percentage descriptive statistical analysis and the instrument for learning outcomes was a post-test with the analysis used was $\mathrm{N}$-Gain. The results showed that the response of students to the application of the PjBL learning model using the tour builder was quite good with the response index criteria of $73 \%$ and there was an increase in student's learning outcomes at each meeting by $0.45 \mathrm{~g}$ based on the gain index. Educators should make the PjBL learning model using a tour builder as an alternative to be applied in class to certain materials, to improve student's learning outcomes.

Keywords: project based learning, tour builder, student response, learning outcomes 


\section{Pendahuluan}

Perencanaan adalah menyusun langkah-langkah yang akan dilaksanakan untuk mencapai tujuan yang telah ditentukan. Perencanaan tersebut dapat disusun berdasarkan kebutuhan dalam jangka waktu tertentu sesuai dengan keinginan pembuat perencanaan, namun yang lebih utama adalah perencanaan yang dibuat harus dapat dilaksanakan dengan mudah dan tepat sasaran. Pembelajaran atau pengajaran adalah upaya untuk mengajarkan siswa. Pengertian pembelajaran ini secara implisit dalam pengajaran terdapat kegiatan memilih, menetapkan, mengembangkan metode untuk mencapai hasil pengajaran yang diinginkan. Pemilihan, penetapan, dan pengembangan metode ini didasarkan pada kondisi pengajaran yang ada. Kegiatan ini pada dasarnya merupakan inti dari perencanaan pembelajaran.

Pada konteks pembelajaran, perencanaan dapat diartikan sebagai proses penyusunan materi pelajaran, penggunaan media pembelajaran, penggunaan pendekatan dan metode pengajaran, serta penilaian dalam suatu alokasi waktu yang akan dilaksanakan pada masa tertentu untuk mencapai tujuan pembelajaran, yang termasuk dalam tujuan pembelajaran ialah pembelajaran yang efektif dan mudah dipahami, sehingga pendidik harus tepat dalam memilih dan cara menyampaikan materi agar bisa tersampaikan dengan baik kepada peserta didik. Pendidik tidak hanya membuat perencanaan pembelajaran saja tetapi harus diterapkan dalam kelas. Implementasi atau penerapan pembelajaran, secara garis besar merupakan suatu tindakan atau pelaksanaan dari sebuah rencana yang disusun secara matang dan terperinci dalam melakukan proses pembelajaran. Pada tahap penerapan pembelajaran inilah pendidik dapat melihat berhasil atau tidak perencanaan tersebut.

Keberhasilan proses pembelajaran merupakan hal utama yang didambakan dalam pelaksanaan pendidikan di sekolah. Proses pembelajaran dikatakan berhasil bila terjadi strukturisasi perubahan dari aspek kognitif, afektif dan psikomotorik siswa. Perubahan tersebut digunakan sebagai salah satu indikasi terselenggaranya proses pembelajaran dengan baik dan tepat. Kualitas pembelajaran di kelas dapat mempengaruhi kualitas hasil pembelajaran.

Pendidik diharapkan mampu membuat variasi model pembelajaran yang membuat peserta didik aktif dalam proses pembelajaran. Peserta didik dilibatkan dalam proses pengumpulan informasi dan mengkonstruksinya, sehingga pembelajaran menjadi menyenangkan. Satu diantaranya adalah penggunaan model pembelajaran yang bervariasi dapat membangkitkan peserta didik agar aktif dalam proses belajar mengajar adalah model Project Based Learning. 
Jurnal geoedusains, Volume 1, Nomor 2, Desember 2020

Model pembelajaran Project Based Learning adalah suatu metode pengajaran sistematis yang melibatkan para siswa dalam mempelajari pengetahuan dan keterampilan melalui proses yang terstruktur, pengalaman nyata dan teliti yang dirancang untuk menghasilkan produk (Sutirman, 2013). Pada proses pembelajaran, guru sebagai komponen paling penting yaitu sebagai pengelola, fasilitator, pembimbing, motivator dan asessmen. Model project based learning (PjBL) merupakan suatu model pembelajaran yang melibatkan suatu proyek dalam proses pembelajaran. Sebagai model yang telah lama diakui kekuatannya dalam mengembangkan kompetensi siswa, banyak para ahli mengungkapkan keunggulan antara lain adalah: (1) meningkatkan motivasi siswa untuk belajar, (2) mendorong kemampuan siswa melakukan pekerjaan penting, (3) mengembangkan kemampuan siswa dalam memecahkan masalah dan berpikir kritis, dll (Direktorat Pembina SMA, 2014).

Tour Builder adalah salah satu geo tool's atau website yang dapat digunakan untuk menceritakan perjalanan ataupun suatu materi geografi, spesialnya pengguna website ini dapat memilih lokasi tepat di peta, menambahkan foto, teks, dan video, lalu dibagikan ke semua orang. Penggunaan tour builder dalam pembelajaran memberikan banyak manfaat bagi pendidik. Salah satunya ialah pendidik dapat menampilkan tempat suatu kejadian fenomena geosfer, sehingga peserta didik lebih mudah mengingat atau bahkan bisa mengingat suatu materi dengan mengetahui lokasi, seperti halnya dapat membaca kondisi alam hanya melalui lokasi. Kemudahan ini diharapkan dapat membantu peserta didik dalam meningkatkan hasil belajar. Penggunaan model pembelajaran berbasis menggunakan media tour builder akan menghasilkan suatu karya online yang dapat dilihat , dibaca dan digunakan oleh siapapun secara gratis.

Penelitian mengenai Implementasi model pembelajaran project based learning untuk melihat respon dan hasil belajar peserta didik tidak banyak dilakukan, meskipun begitu ada beberapa penelitian yang telah dilakukan. Menurut Ekapti (2016) siswa memberikan respon yang positif terhadap pengunaan model pembelajaran PjBL dan memberikan perubahan yang baik pada hasil belajar (Ekapti, 2016). Menurut Nur, Abdi, Amri (2016) Respon siswa terhadap model project based learning dapat dikatakan baik sekali dengan 80\% dari 25 siswa berpendapat bahwa pembelajaran menggunakan PjBL dapat meningkatkan pemahaman mereka terhadap materi hubungan manusia dan lingkungan akibat dinamika hidrosfer yang telah dipelajari (Nur, Abdi, \& Amri, 2016). Menurut Yusrizal, dan Nurmaliah (2016) penggunaan model pembelajaran PjBL dapat memberikan respon atau tanggapan yang baik pada siswa, karena dapat membantu siswa dalam berpikir kritis, 
Jurnal geoedusains, Volume 1, Nomor 2, Desember 2020

aktif dalam diskusi tentang hipotesis, tanya jawab serta menarik kesimpulan dari fluida statis tersebut (Rauziani, Yusrizal, \& Nurmaliah, 2016).

Berdasarkan uraian di atas perlu dikembangkan suatu tindakan yang dapat membantu peserta didik dalam melaksanakan pembelajaran geografi sehingga mata pelajaran geografi lebih menarik, bervariasi dan materi geografi dapat divisualisasikan secara konkret di dalam kelas, maka peneliti tertarik untuk mengambil penelitian ini, yang berjudul "Penerapan Model Pembelajaran Project Based Learning Menggunakan Aplikasi Tour Builder terhadap Hasil Belajar Geografi Kelas X SMA Negeri 1 Kaliorang".

\section{Metode}

Penelitian ini memilih desain Pre-Experimental Design, dengan pertimbangan bahwa masih terdapat variable ekstra yang ikut terpengaruh terhadap terbentuknya variabel terikat. Jadi hasil eksperimen yang yang merupakan variabel terikat itu bukan sematamata dipengaruhi oleh variabel bebas. Hal ini dapat terjadi, karena tidak adanya variabel kontrol, dan sampel tidak dipilih secara random.

Penelitian ini memiliki rancangan Time Series Design sebagaimana yang disajikan dalam tabel di bawah ini :

Tabel 1 Rancangan penelitian Time Series Design

\begin{tabular}{ccccccccc}
\hline Group & Perlakuan & Tes & Perlakuan & Tes & Perlakuan & Tes & Perlakuan & Tes \\
\hline Eksperimen & $\mathrm{X}$ & $\mathrm{O}$ & $\mathrm{X}$ & $\mathrm{O}$ & $\mathrm{X}$ & $\mathrm{O}$ & $\mathrm{X}$ & $\mathrm{O}$ \\
\hline
\end{tabular}

Keterangan:

$\mathrm{X}$ : Diberikan perlakuan berupa penggunaan model pembelajaran project based learning menggunakan tour builder

$\mathrm{O}:$ Pemberian pretest

Penelitian ini menguji coba model pembelajaran project based learning dan tour builder pada peserta didik yang minim pengetahuan pada dua hal tersebut, pendidik akan memberikan sedikit pemaparan kemudian peserta didik akan dibagi dalam kelompok yang terdiri dari tiga orang. Selama pembuatan proyek peserta didik berhak konsultasi atau bertanya pada pendidik. Setiap akhir pertemuan peserta didik akan mengerjakan uji kompetensi, untuk melihat peningkatan kemampuan peserta didik setiap pertemuan. Pada pertemuan ke empat, peserta didik akan mengisi angket tentang model pembelajaran dan media tour builder. Angket dianalisis menggunakan statistik deskriptif persentase dan hasil belajar belajar atau tes dianalisis menggunakan N-Gain.

Sampel dalam penelitian ini diambil secara teknik sampling jenuh yaitu teknik penentuan sampel bila semua anggota populasi digunakan sebagai sampel. Sampel yang Penerapan Model Pembelajaran Problem Based Learning ... 
Jurnal geoedusains, Volume 1, Nomor 2, Desember 2020 digunakan dalam penelitian ini adalah siswa kelas X IImu Pengetahuan Sosial di SMA Negeri 1 Kaliorang yang berjumlah 32 orang.

Instrument yang digunakan untuk mengetahui respon peserta didik terhadap model pembelajaran project based learning menggunakan tour builder adalah angket yang terdiri dari 20 butir soal dengan empat pilihan yaitu sangat setuju, setuju, kurang setuju dan tidak setuju. Aspek dalam angket yang digunakan untuk melihat respon siswa ialah ketertarikan terhadap model pembelajaran, terhadap media pembelajaran yang digunakan yaitu tour builder dan terhadap hasil belajar yang dicapai setelah peserta didik mengikuti proses belajar mengajar dalam kelas. Mengetahui persentase respon siswa dilakukan analisis statistik deskriptif persentase, berdasarkan indeks kriteria yang telah ditentukan.

Cara melihat hasil belajar dalam penelitian ini dengan memberikan 10 soal setiap pertemuan dengan indikator pencapaian hasil belajar seluruh siswa di atas kriteria ketuntasan minimal yang telah ditentukan. Pemberian tes setiap pertemuan dapat mengetahui setiap perubahan atau peningkatan hasil belajar siswa. Hasil belajar siswa di hitung menggunakan analisis deskriptif dengan kriteria ketuntasan minimal.

\section{Hasil dan Pembahasan}

\section{Hasil Penelitian}

1. Respon peserta peserta didik terhadap model pembelajaran project based learning menggunakan tour builder

Penelitian yang dilakukan di SMA Negeri 1 Kaliorang pada kelas X IPS dengan jumlah siswa 32 orang, semester 1 materi hidrosfer dengan tujuan untuk mengetahui respon peserta didik dan hasil belajar terhadap model pembelajaran PjBL menggunakan tour builder. Secara umum penelitian berjalan dengan cukup baik, mulai dari peneliti bersosialisasi dengan guru geografi dan pihak-pihak yang terkait lainnya hingga proses penelitian berakhir. Penelitian ini dilakukan dari tanggal 16 Maret - 20 Mei 2020. Selama proses penelitian berlangsung, kondisi lingkungan belajar dapat terkendali dengan baik.

Penelitian ini menerapkan model pembelajaran project based learning menggunakan aplikasi tour builder pada satu kelas. Dilakukan sebanyak 4 kali pertemuan, 3 pertemuan terakhir dilakukan secara online karena adanya peristiwa pandemik covid-19. Penelitian ini dilakukan untuk mengetahui respon peserta didik pada model pembelajaran project based learning menggunakan tour builder melalui angket tertutup yang terdiri pernyataan positif dan pernyataan negatif, memiliki 20 butir. 
Jurnal geoedusains, Volume 1, Nomor 2, Desember 2020

Angket terdiri dari aspek pembelajaran dan pemahaman materi siswa seperti ketertarikan peserta didik dalam pembelajaran menggunakan model pembelajaran tersebut, timbal balik peserta didik dalam proses pembelajaran, peserta didik merasa terbantu memahami materi geografi dengan adanya model pembelajaran project based learning, dan motivasi peserta didik untuk mengikuti proses pembelajaran. Aspek selanjutnya adalah media pembelajaran yang digunakan yaitu tour builder, indikator yang dilihat yaitu membantu peserta didik dalam belajar dan memahami materi geografi secara konkret. Aspek terakhir yang dilihat dalam mengetahui respon peserta didik adalah model pembelajaran dan media yang digunakan dapat mengetahui hasil belajar peserta didik seperti dalam menyelesaikan uji kompetensi.

Angket diberikan kepada peserta didik pada pertemuan terakhir setelah mengikuti empat pertemuan. Peserta didik hanya perlu mengisi chek list pada tabel yang berisi sangat setuju, setuju, cukup setuju, dan tidak setuju. Berikut grafik respon peserta didik setelah mengikuti proses pembelajaran menggunakan model pembelajaran project based learning menggunakan tour builder. Berikut disajikan diagram angket respon peserta didik, dimana huruf (sumbu $\mathrm{X}$ ) adalah pernyataan angket dan angka (sumbu Y) adalah jumlah memilih. menggunakan tour builder.

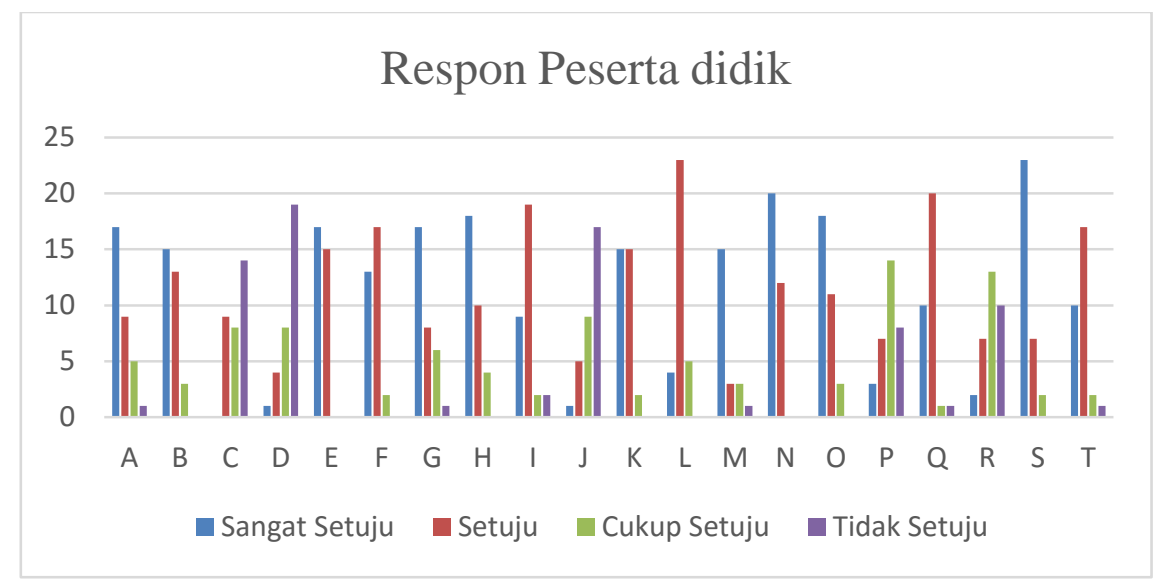

Gambar 1 Diagram Respon Siswa Kelas X IPS kelompok 1

Berdasarkan gambar di atas pernyataan A- M merupakan pernyataan terhadap model pembelajaran PjBL, dimana empat diantaranya merupakan pernyataan negatif. Pernyataan $\mathrm{C}, \mathrm{D}$ dan $\mathrm{J}$ sangat banyak yang memilih tidak setuju, dimana pernyataan tersebut merupakan pernyataan negatif tentang model PjBL ini. Pernyataan lainnya merupakan positif dan diagram paling tinggi berwarna merah pada pernyataan $L$ tentang ketertarikan peserta didik terhadap pelajaran geografi menggunakan model pembelajaran PjBL. Pernyataan N-R merupakan pernyataan terhadap tour builder, dua diantaranya yaitu $\mathrm{P}$ dan $\mathrm{R}$ merupakan pernyataan negatif. 
Jurnal geoedusains, Volume 1, Nomor 2, Desember 2020

Pernyataan $\mathrm{S}$ dan $\mathrm{T}$ merupakan pernyataan pengaruh model pembelajaran $\mathrm{PJBL}$ terhadap kerja kelompok dan hasil belajar peserta didik. Diagram merah dan biru menunjukkan bahwa siswa terbantu dengan penerapan model project based learning menggunakan tour builder. Dibawah ini merupakan tabel analisis deskriptif pernyataan peserta didik secara keseluruhan terhadap penerapan model pembelajaran PjBL menggunakan tour builder.

Tabel 2 Analisis deskriptif respon siswa kelas X IPS

\begin{tabular}{|c|c|c|c|c|c|}
\hline \multicolumn{7}{|c|}{ Descriptive Statistics } \\
\hline & $\mathrm{N}$ & Minimum & Maksimum & Mean & Modus \\
\hline Sangat Setuju & 32 & 1 & 14 & 6,94 & 7 \\
\hline Setuju & 32 & 1 & 15 & 7,34 & 7 \\
\hline Cukup Setuju & 32 & 0 & 6 & 2,75 & 1 \\
\hline Tidak Setuju & 32 & 0 & 8 & 2,94 & 3 \\
\hline
\end{tabular}

Berdasarkan analisis deskriptif data respon, diperoleh peserta didik paling banyak memilih setuju dalam penerapan model pembelajaran project based learning menggunakan tour builder. Terdapat banyak faktor yang mempengaruhi siswa sehingga hanya memilih setuju dibanding memilih sangat setuju, salah satunya karena proses pembelajaran yang dilakukan secara online membuat kurangnya interaksi secara langsung.

2. Hasil belajar siswa setelah diterapkan model pembelajaran project based learning menggunakan tour builder

Penelitian ini juga melihat hasil belajar peserta didik, setelah diterapkannya model pembelajaran project based learning menggunakan tour builder melalui post test yang dilakukan setiap akhir pertemuan yaitu sebanyak empat kali, sehingga dapat terlihat perubahan. Hasil belajar adalah perubahan pencapaian hasil belajar peserta didik, baik itu berupa afektif, kognitif dan psikomotorik yang diperoleh dari kegiatan pembelajaran peserta didik di SMA Negeri 1 Kaliorang, Kecamatan Kaliorang, Kabupaten Kutai Timur, setelah pendidik menggunakan model pembelajaran project based learning, baik yang ditunjukkan oleh peningkatan angka dalam nilai, ilmu pengetahuan, sikap, maupun pengalaman nilai dalam periode tertentu.

Cara melihat hasil belajar dalam penelitian ini dengan cara pemberian 10 soal setiap pertemuan dengan indikator pencapaian hasil belajar seluruh peserta didik di atas kriteria ketuntasan minimal yang telah ditentukan. Data tentang hasil belajar setiap pertemuan disajikan dalam bentuk diagram yang dibagi menjadi dua agar terlihat jelas setiap siswa pada pertemuan satu sampai empat seperti di bawah ini. 


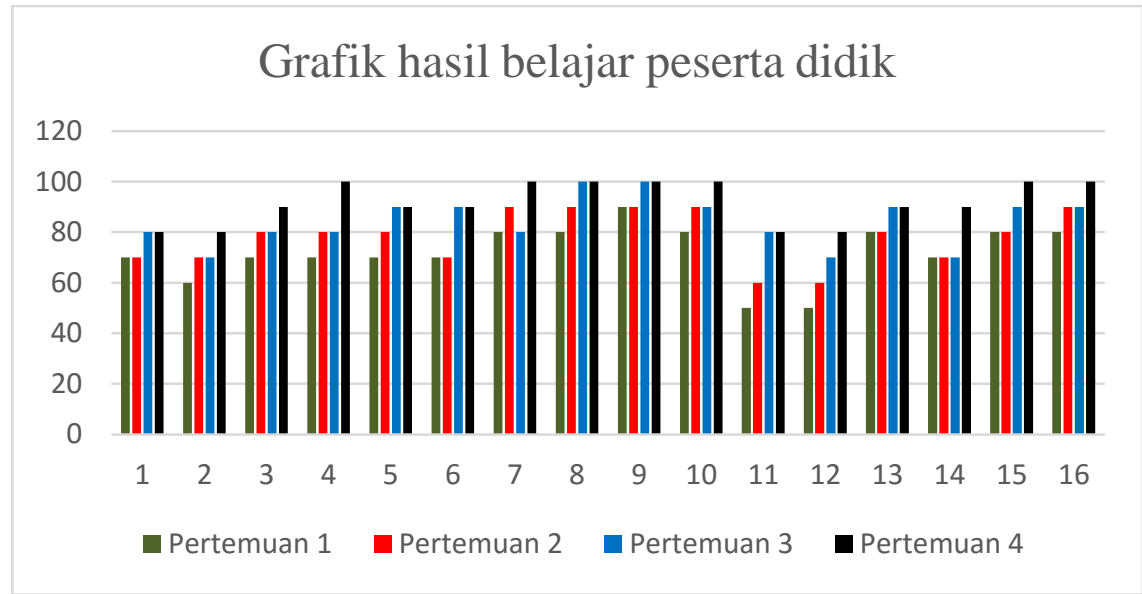

Gambar 2 Diagram Hasil Belajar Kelas X IPS Kelompok 1

Gambar diagram diatas menunjukkan peningkatan hasil belajar peserta didik kelas $X$ IPS kelompok 1 setiap pertemuan, secara garis besar seluruh peserta didik mengalami peningkatan hasil belajar setiap pertemuan. Terdapat beberapa peserta didik yang mempunyai nilai yang sama pada pertemuan 3 dan 4 , hal ini terjadi karena beberapa faktor, diantaranya 1) kemampuan peserta didik sudah cukup baik dalam memahami materi yang ada, 2) peserta didik aktif berdiskusi dalam kelompok 3) kritis terhadap materi sehingga banyak bertanya, dan 4) aktif mencari informasiinformasi baru. Dibawah ini disajikan diagram hasil belajar siswa kelas $X$ IPS kelompok 2.

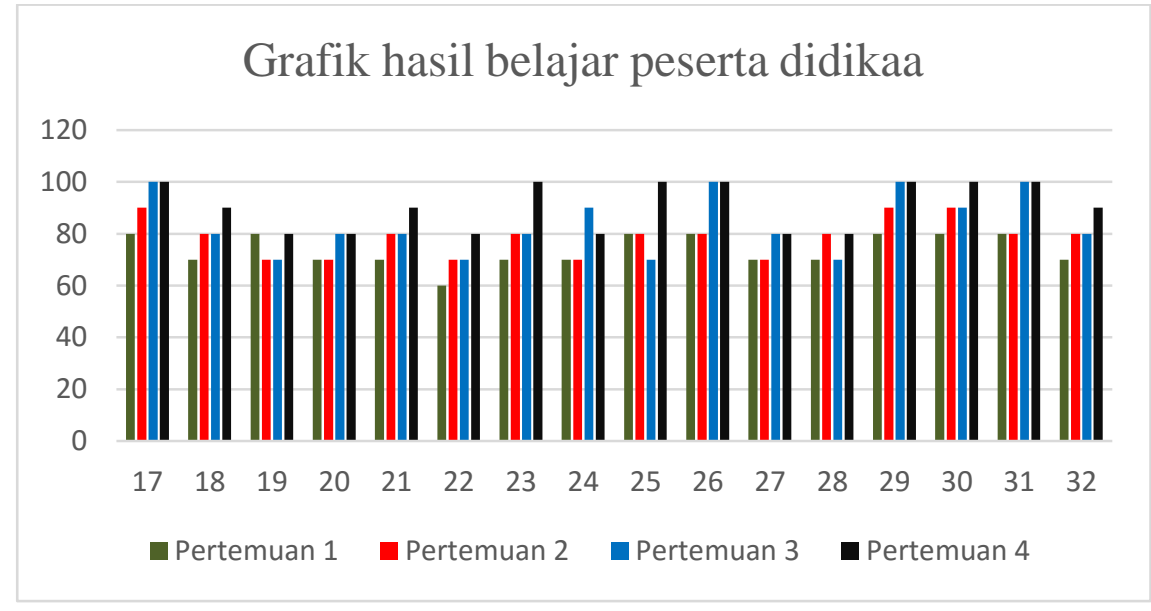

Gambar 3 Diagram Hasil Penelitian Kelas X IPS

Berdasarkan diagram di atas, hanya lima diantara tiga puluh dua peserta didik yang nilainya mengalami penurunan antara pertemuan satu sampai tiga dan naik pada pertemuan terakhir. Peserta didik yang tidak mengalami peningkatan terjadi karena kurang antusias dalam belajar dalam kelas, baik pada pelajaran geografi dan pelajaran lainnya, belum beradaptasi dengan model pembelajaran dan media yang digunakan serta kurangnya motivasi dalam belajar. Peserta didik lainnya mengalami 
Jurnal geoedusains, Volume 1, Nomor 2, Desember 2020 kenaikan dari pertemuan pertama ke pertemuan kedua, pertemuan kedua ke pertemuan ketiga dan terdapat beberapa juga yang nilainya sama pada pertemuan kedua ke pertemuan ketiga, begitu juga pertemuan selanjutnya. Berikut disajikan analisis deskriptif hasil belajar peserta didik kelas X IPS setiap pertemuan.

Tabel 3 Analisis deskriptif Hasil Belajar Siswa Kelas X IPS

\begin{tabular}{|l|c|c|c|c|c|}
\hline \multicolumn{7}{|c|}{ Descriptive Statistics } \\
\hline & $\mathrm{N}$ & Minimum & Maksimum & Mean & Modus \\
\hline Pertemuan 1 & 32 & 50 & 90 & 72,81 & 7,5 \\
\hline Pertemuan 2 & 32 & 60 & 90 & 78,44 & 80 \\
\hline Pertemuan 3 & 32 & 70 & 100 & 84,06 & 80 \\
\hline Pertemuan 4 & 32 & 80 & 100 & 91,56 & 100 \\
\hline
\end{tabular}

Berdasarkan hasil analisis deskriptif hasil belajar di atas, dapat diketahui bahwa nilai minimum setiap pertemuan selalu mengalami peningkatan, begitu juga nilai maksimum yang selalu mengalami peningkatan. Nilai rata-rata peserta didik pada pertemuan pertama tidak mencapai kriteria ketuntasan minimal namun pertemuan selanjutnya cukup baik. Dibawah ini disajikan diagram nilai rata-rata hasil belajar setiap pertemuan.

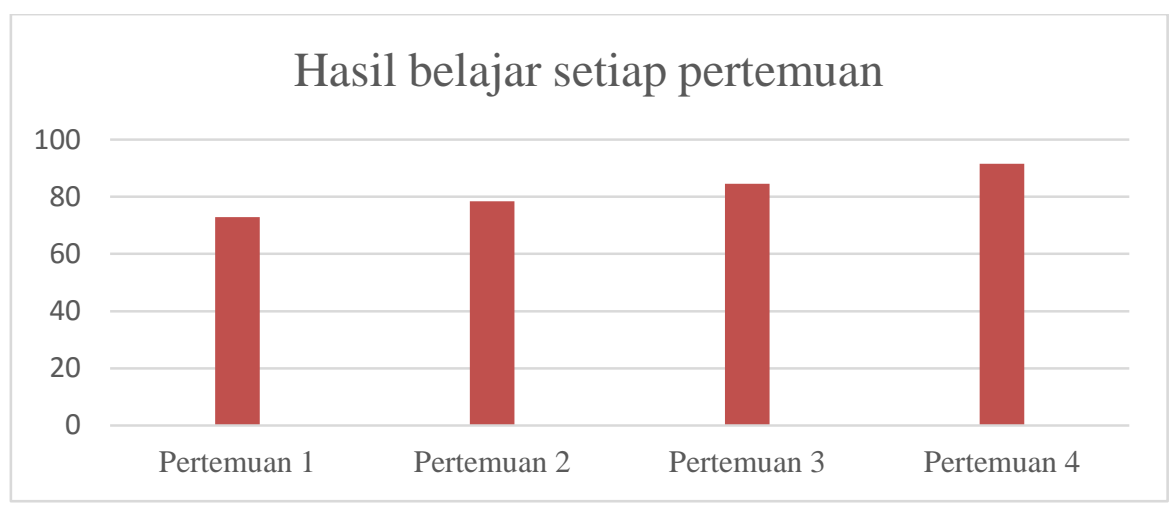

Gambar 4 Diagram Nilai Rata-Rata Hasil Belajar Peserta Didik

Berdasarkan gambar diatas dapat diketahui bahwa peserta didik mengalami peningkatan hasil belajar setiap pertemuan, meskipun perubahan tersebut tidak terjadi secara signifikan. Hal ini cukup membuktikan bahwa penerapan model pembelajaran project based learning menggunakan tour builder dapat memperbaiki atau mempengaruhi hasil belajar peserta didik kelas X IPS.

\section{Pembahasan}

1. Respon peserta didik dalam penerapan model pembelajaran project based learning menggunakan tour builder 
Jurnal geoedusains, Volume 1, Nomor 2, Desember 2020

Berdasarkan hasil analisis data respon yang telah dilakukan peneliti, hasil penelitian ini sedikit berbeda dengan peneliti sebelumnya yang melihat respon dengan menggunakan model pembelajaran project based learning. Hasil penelitian yang dilakukan di SMA Negeri 11 Banda Aceh menjelaskan bahwa Implementasi model pembelajaran project based learning untuk meningkatkan hasil belajar geografi Siswa Kelas X SMA Negeri 11 Banda Aceh mendapat respon yang baik sekali (Nur, Abdi, \& Amri, 2016). Hasil penelitian tersebut cukup berbeda dengan penelitian ini penerapan model pembelajaran project based learning menggunakan tour builder yang hanya mendapat respon cukup baik.

Penelitian sebelumnya yang serupa dengan melihat respon peserta didik menggunakan model pembelajaran project based learning juga dilakukan di Banda Aceh. Penelitian tersebut menjelaskan bahwa implementasi model project based learning (Pjbl) dalam meningkatkan hasil belajar dan berpikir kritis siswa pada materi fluida statis di SMA Inshafuddin mendapat respon yang baik pada siswa (Rauziani, Yuzrial, \& Nurmaliah 2016). Hasil penelitian tersebut sedikit berbeda dengan hasil penelitian penerapan model pembelajaran project based learning menggunakan tour builder, yang hanya mendapatkan respon siswa cukup baik setelah mengikuti proses pembelajaran menggunakan model project based learning adalah cukup baik dengan peresentase nilai $73 \%$.

Faktor yang membuat model pembelajaran ini hanya mendapat respon yang cukup baik salah satunya karena proses pembelajaran dilakukan secara online, sehingga peserta didik cukup sulit untuk memahami langkah-langkah model pembelajaran project based learning, selain itu juga karena keterbatasan listrik di rumah peserta didik sehingga membutuhkan waktu yang cukup lama untuk menyelesaikan tugas, kemudian waktu belajar secara online dilakukan pada malam hari. Latar belakang peserta didik yang memilih cukup setuju dan tidak setuju dalam penerapan model pembelajaran project based learning menggunakan tour builder dikarenakan harus membutuhkan kuota internet, harus membutuhkan listrik sedangkan di rumah peserta didik belum tersedia listrik 24 jam, harus dibuat menggunakan laptop dimana tidak semua peserta didik mempunyai laptop dimana terdapat beberapa peserta didik yang masih minim dalam menggunakan laptop.

Jika dilihat dari diagram respon dan nilai maksimum respon peserta didik memilih setuju dalam penerapan model pembelajaran ini, dikarenakan penggunaan tour builder sangat membantu dalam memahami pelajaran geografi dengan merealisasikan materi-materi yang tidak bisa dibawa ke dalam kelas, peserta didik 
Jurnal geoedusains, Volume 1, Nomor 2, Desember 2020

mudah mengingat dengan memberi tanda langsung pada peta dan langsung mencantumkan teori penjelasannya. Seperti halnya kelebihan tour builder yang memperkaya tour dengan fitur penambah data multimedia pada proyek yang dibuat misalnya foto, klip video dan teks.

Peserta didik merasa lebih terbantu dengan tour builder karena dapat melihat morfologi bumi secara langsung yang tidak bisa di lihat pada peta atau globe. Peserta didik juga dapat menyelesaikan tugas yang diberikan oleh guru dengan baik. Hal tersebut dapat diketahui dengan melihat siswa dapat merancang atau menyelesaikan proyek yang diberikan oleh guru dengan baik.

Seperti menurut Sudrajat (dalam Putri, 2011) mengemukakan fungsi media diantaranya yaitu a) Media pembelajaran dapat mengatasi keterbatasan pengalaman yang dimiliki oleh para siswa. b) Media pembelajaran dapat melampaui batasan ruang kelas. c) Media pembelajaran memungkinkan adanya interaksi langsung antara siswa dengan lingkungan. d) Media menghasilkan keseragaman pengamatan. e) Media dapat menanamkan konsep dasar yang benar, konkret, dan realistis. f) Media membangkitkan motivasi dan merangsang anak untuk belajar. g) Media memberikan pengalaman yang integral/menyeluruh dari yang kongkrit sampai dengan abstrak.

2. Hasil belajar peserta didik setelah penerapan model pembelajaran project based learning menggunakan tour builder

Berdasarkan hasil analisis data yang telah dilakukan peneliti, hasil penelitian ini tidak jauh berbeda dengan penelitian sebelumnya yang menerapkan model pembelajaran project based learning menggunakan tour builder. Hasil penelitian yang dilakukan di SMA Al-Azhar 3 Bandar Lampung, menjelaskan bahwa ada pengaruh yang signifikan model pembelajaran project based learning terhadap hasil belajar geografi (Triani, 2015). Peneliti lain yang serupa juga dilakukan di SMA Negeri 2 Sungai Raya, menjelaskan bahwa model project based learning memberikan berpengaruh tinggi terhadap hasil belajar geografi siswa kelas X IPS SMA Negeri 2 Sungai Raya.

Penelitian lain yang serupa juga tidak jauh berbeda dengan penelitian yang dilakukan di Banda Aceh yaitu Implementasi model pembelajaran project based learning untuk meningkatkan hasil belajar geografi Siswa Kelas X SMA Negeri 11, yang menjelaskan bahwa model project based learning dapat meningkatkan pemahaman siswa. Hasil penelitian ini juga menjelaskan bahwa penerapan model pembelajaran project based learning menggunakan tour builder berpengaruh Penerapan Model Pembelajaran Problem Based Learning ... 104 Kusnayati, Komariyah Laili, Widya Saputra Yulian 
Jurnal geoedusains, Volume 1, Nomor 2, Desember 2020

terhadap hasil belajar sehingga peserta didik dapat meningkatkan pemahaman materi dinamika hidrosfer dan dampaknya terhadap kehidupan.

Peningkatan hasil belajar terjadi dari pertemuan pertama hingga pertemuan terakhir, meskipun peningkatan tidak terjadi secara signifikan namun terjadi setiap pertemuan. Suasana kelas pada pertemuan pertama yang dilakukan secara tatap muka dalam kelas masih tidak kondusif, banyak peserta didik yang ribut, bermain dalam kelas, mengobrol dengan teman kelompok atau keluar masuk kelas dengan alasan izin ke toilet, sehingga peserta didik kurang memperhatikan guru dalam menjelaskan materi ataupun mengikuti proses pembelajaran, hal-hal tersebut merupakan salah satu alasan yang membuat pada pertemuan pertama peserta didik mendapatkan nilai rata-rata 72,81 dimana peserta didik paling banyak mendapatkan nilai 70 dan 80 , nilai peserta didik paling rendah adalah 50 dan nilai peserta didik paling tinggi adalah 90 .

Pertemuan ke dua, meskipun dilakukan secara online peserta didik mulai memahami langkah-langkah dan mulai mengikuti proses pembelajaran, sehingga pada pertemuan ini peserta didik mulai mengalami peningkatan hasil belajar dengan nilai rata-rata 78,4 dimana nilai siswa paling tinggi mendapat 80 dan nilai siswa paling rendah 60. Pertemuan ini peserta didik belum paham membuat tour builder dengan kelompoknya sehingga waktu untuk menyelesaikan proyek masih lebih lama. Pertemuan ke tiga peserta didik mengikuti proses pembelajaran dengan project based learning cukup baik dan cukup memahami cara membuat tour builder. Peningkatan hasil belajar peserta didik cukup baik dengan nilai rata-rata 84, dimana nilai peserta didik paling rendah adalah 70 dan nilai peserta didik paling tinggi adalah 100.

Pertemuan ke empat, peserta didik sudah mulai mengikuti dengan baik proses pembelajaran menggunakan model pembelajaran project based learning dan cara membuat atau menggunakan tour builder dengan baik. Pertemuan ini nilai rata-rata siswa adalah 91,56 dengan nilai peserta didik paling rendah adalah 80 dan nilai peserta didik paling tinggi adalah 100. Waktu penyelesaian proyek pada pertemuan ke empat lebih cepat dibanding sebelumnya, hal ini membuktikan bahwa peserta didik sangat antusias pada penggunaan tour builder dalam proses pembelajaran.

Secara umum, pembelajaran geografi dengan menerapkan model pembelajaran project based learning menggunakan tour builder dapat meningkatkan hasil belajar siswa. Berdasarkan kriteria indeks gain, model pembelajaran project based learning dan tour builder yang digunakan cukup efektif dengan skor gain $70 \%$ yang termasuk 
Jurnal geoedusains, Volume 1, Nomor 2, Desember 2020

dalam kategori sedang. Terdapat beberapa kelemahan pada model pembelajaran ini dan tour builder, diantaranya ialah kemampuan atau pengetahuan dasar peserta didik dalam mengoperasikan laptop atau komputer, ketersediaan Isitrik di rumah peserta didik karena pada penelitian ini proses pembelajaran dilakukan secara online dan ketersediaan komputer atau laptop. Membutuhkan waktu yang cukup lama karena penyelesaian proyek tidak secara langsung dibimbing oleh guru.

Beberapa kelebihan menggunakan model pembelajaran project based learning dan tour builder pada proses pembelajara secara online adalah peserta didik lebih cepat memahami materi, lebih banyak belajar dari berbagai sumber, lebih kreatif dalam mencari sumber-sumber materi, dapat berkerjasama dengan baik dalam kelompok dan menghargai waktu.

\section{Kesimpulan}

Berdasarkan hasil penelitian dan pembahasan dapat disimpulkan bahwa:

1. Respon peserta didik SMA Negeri 1 Kaliorang terhadap model pembelajaran project based learning menggunakan tour builder termasuk dalam kategori cukup baik dengan persentase nilai $73 \%$.

2. Terdapat peningkatan hasil belajar peserta didik kelas X IPS dari setiap pertemuan dengan nilai rata-rata 72,8 pada pertemuan 1 , nilai rata-rata 78,4 pada pertemuan 2 , nilai rata-rata 84 pada pertemuan 3, dan nilai rata-rata 91 pada pertemuan 4 .

\section{Daftar Pustaka}

Direktorat Pembina SMA. 2014. Pembelajaran Geografi Melalui Pendekatan Saintifik. Jakarta: Direktorat Pendidikan Menengah Kementerian Pendidikan dan Kebudayaan.

Ekapati, Fahmi Faradisya. 2016. "Respon Siswa Dan Guru Dalam Pembelajaran IPA Terpadu Konsep Tekanan Melalui Problem Based Learning". Jurnal Pena Sains Vol. 3, No. 2, Oktober 2016

Nur, Aulia, Abdul Wahab dan Amsal Amri. 2016. "Implementasi Model Pembelajaran Project Based Learning untuk Meningkatkan Hasil Belajar Geografi Siswa Kelas X Sma Negeri 11 Banda Aceh". Jurnal Ilimiah Mahasiswa Pendidikan Geografi Vol. 1, No.2 2016.

Putri, Agustina. 2011. Psikologi Perkembangan. Surakarta: PGSD UMS.

Rauziani, Yusrizal, dan Cut Nurmaliah. "Implementasi Model Project Based Learning (Pjbl) dalam Meningkatkan Hasil Belajar dan Berpikir Kritis Siswa pada Materi Fluida Statis Di Sma Inshafuddin". 2017. Jurnal Pendidikan Sains Indonesia Vol. 4, No. 2, 2016.

Suminarsih, Eka. "Penerapan Model Pembelajaran Project Based Learning pada Pembelajaran Geografi terhadap Hasil Belajar Siswa Kelas X SMA Negeri 2 Sungai Raya". 15 Januari 2019.

Sutirman. 2013. Media dan Model-Model Pembelajaran Inovatif. Yogyakarta: Graha Ilmu. 